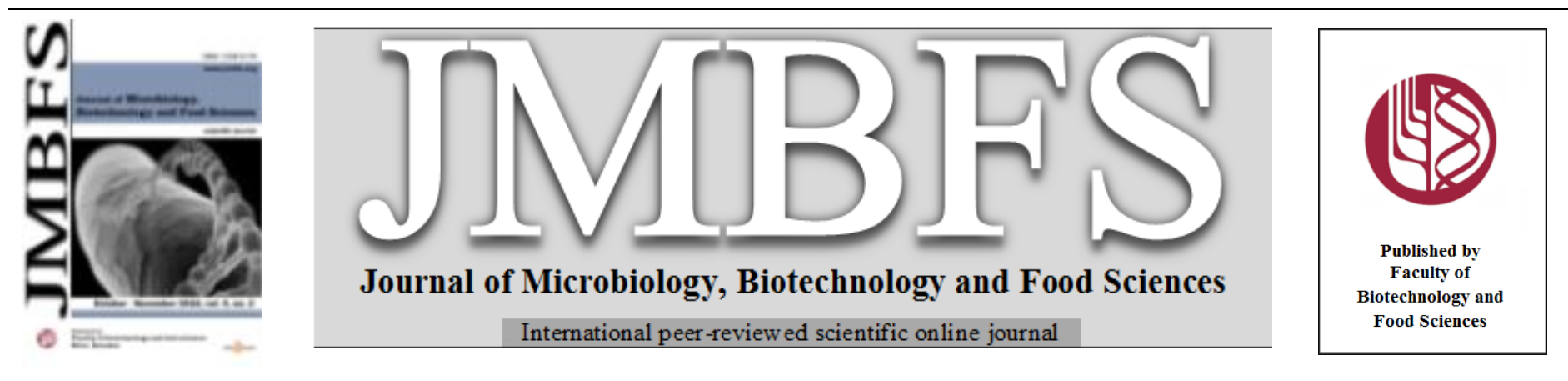

\title{
IN VITRO EFFICACY OF BRACKET FUNGI FOR THEIR POTENTIAL ANTIMICROBIAL ACTIVITY
}

\section{Vipin Parkash ${ }^{1}$, Anita Sharma ${ }^{2}$}

\author{
Address(es): Vipin Parkash, PhD \\ ${ }^{1}$ Rain Forest Research Institute (Indian Council Forestry Research \& Education), Silviculture \& Forest Management Division, Deovan, Jorhat-785001, Assam, India. \\ Contact: +91-94355-70331. \\ ${ }^{2}$ Biotechnology Department, Shoolini Institute Life Sciences \& Business Management, Anand Campus, Near Head Post Office, The Mall, Solan-173212, Himachal \\ Pradesh, India.
}

*Corresponding author: bhardwajvpnpark@ rediffmail.com

doi: 10.15414/jmbfs.2016.6.2.818-822

\section{ARTICLE INFO}

Received 27. 4. 2015

Revised 12.11.2015

Accepted 12. 7. 2016

Published 3. 10. 2016

Regular article OPEN $\partial_{\text {ACCESS }}$

\begin{abstract}
This study was conceptualized to reveal the anti-microbial potential of bracket fungi, viz. - Ganoderma lucidum (Curtis) Karst. and Polyporus officinalis (syn. Laricifomes officinalis) (Vill.) Fr. extracts through in vitro approach. The aqueous and ethanolic extracts were assessed against four phytopathogenic fungi (Alternaria solani, Curvularia lunata, Aspergillus terreus and Fusarium oxysporum) along with bacteria (Escherichia coli and Bacillus subtilis). Ethanolic extract of G. lucidum had significant growth inhibition effect against $A$. solani, $C$. lunata, A. terreus and $F$. oxysporum at $500 \mathrm{ppm}$ and $1000 \mathrm{ppm}$ concentrations. On the other hand, aqueous extract showed complete inhibition at $1000 \mathrm{ppm}$ and 500ppm concentrations against $A$. terreus and $F$. oxysporum. Ethanolic extract of $P$. officinalis, complete fungal growth inhibition was observed against $A$. solani and A. terreus at 1000ppm concentration while for $C$. lunata and $F$. oxysporum, complete inhibition was observed at $1000 \mathrm{ppm}$ and $250 \mathrm{ppm}$ concentration. Similarly, the aqueous extract of same bracket fungus, showed maximum inhibition of A. solani, A. terreus and $F$. oxysporum at $1000 \mathrm{ppm}$ concentration but $C$. lunata had maximum inhibition at 250ppm concentration. The antibacterial action of ethanolic extract of $G$. lucidum was observed against $E$. coli having inhibitory zone $(0.09 \mathrm{~mm})$ at $1000 \mathrm{ppm}$ concentration and $B$. subtilis had inhibitory zone $(0.05 \mathrm{~mm})$ at $250 \mathrm{ppm}$ concentration. But no inhibitory zones were observed in $E$. coli and B. subtilis with aqueous extract of G. lucidum. Whereas, the ethanolic extract of $P$. officinalis showed a maximum inhibitory zone $(10 \mathrm{~mm})$ at $1000 \mathrm{ppm}$ concentration for $E$. coli and a remarkable inhibitory zone $(0.2 \mathrm{~mm})$ at $250 \mathrm{ppm}$ concentration for $B$. subtilis. While an inhibitory zone $(0.3 \mathrm{~mm})$ was observed in $E$. coli at 250 ppm concentration of aqueous extract, but no inhibitory zone was observed for $B$. subtilis at any concentration of the aqueous extract of $P$. officinalis. Based on the study, it can be concluded that $G$. lucidum and P. officinalis are having considerable potential as anti-fungal and anti-bacterial action, respectively.
\end{abstract}

Keywords: Antimycotic activity, Antibacterial action, Bracket macro-fungi, Minimum inhibitory concentration, Percent fungal growth inhibition

\section{INTRODUCTION}

Human use of fungi for food preparation or preservation and other purposes is extensive and has a long history. Mushroom farming and gathering are large industries in many countries. Many fungi are producers of antibiotics such as penicillin, cephalosporin. Widespread use of these antibiotics for the treatment of bacterial diseases such as tuberculosis, syphilis, leprosy, and many others began in the early $20^{\text {th }}$ century and continues to play a major part in anti-bacteria chemotherapy.

Polypores and bracket fungi are members of the Aphyllophorales, a group of morphologically complex, terrestrial basidiomycetes. Many of these fungi are saprobic wood decayers and as such, these fungi are most often found on logs, stumps, or other dead wood. These fungi also exhibit medicinal properties and used in remedies of various human ailments. There are some reports that revealed their medicinal usages and biological activities. Johnston (2005) reported that Ganoderma lucidum is used in TCM (Traditional Chinese Medicine) for the treatment of cancers. Sliva (2006) and Stanley et al. (2005) also mentioned that G. lucidum is popular medicinal mushroom and used in TCM in Asian countries over the past two millennia and preserve human vitality and promote longevity. G. lucidum is one of the most used "herbs" in Asia and preclinical studies have established that the polysaccharide fractions have potent effects (Chen $\boldsymbol{e t}$ al. 2006). Lin et al. (2006) referred G. tsugae Murrill as the Chinese mushroom 'Songshan lingzhi', which is cultivated in Taiwan and used extensively to treat diseases. Stanley et al. (2005) have demonstrated that G. lucidum induces apoptosis, inhibits cell proliferation and suppress cell migration of highly invasive human prostrate cancer cells PC-3. Pero et al. (2005) reported that combination of extracts of Cordyceps sinensis (Berk.) Sacc., Grifola blazei Gray,
G. frondosa (Dicks.) Gray, Trametes versicolor (L.) Lloyd and G. lucidum into a formulation designed to optimise different modes of immuno-stimulatory actions and yet that would avoid metabolic antioxidant competition. The activities of hypertension, hyperglymecia, hepatitis, chronic bronchitis, bronchical asthma, liver protection and others have been demonstrated from the fruiting bodies and cultured mycelia of G. lucidum (Yuen and Gohel, 2005). Shieh et al. (2001) concluded that the hepatic and renal protective mechanism of G. lucidum might be because of its superoxide scavenging effect. Later, Lakshmi et al. (2006) studied the antimutagenic activity of the methanolic extract of the fruiting bodies of Ganoderma lucidum occurring in South India. The activity was assayed by Ames Salmonella mutageniticity test using histidine mutants of Salmonella typhimurium tester strains. The result revealed that G. lucidum extract restored antioxidant defence and prevented hepatic damage. Beside this, several compounds with Biomedicinal properties like triterpenoids (Kim and Kim, 1999) and polysaccharides (Bao et al., 2002) have been isolated from Ganoderma species.

The extract of Ganoderma lucidum also showed inhibitory actions against pathogenic fungi and bacteria. Wang and Ng (2006) isolated 'Ganodermin', an antifungal protein from fruiting bodies of G. lucidum (Curtis) Karst. Ganodermin inhibited the mycelial growth of Botrytis cinerea Pers., Fusarium oxysporum Schlecht. and Physalaspora piricola Nose. Wang et al. (2006) isolated an antifungal polypeptide from fresh fruiting bodies of Polyporus alveolaris (DC.) Bond. \& Sing.. The antifungal polypeptide, designated as alveolarin, had demonstrated an inhibitory action on mycelial growth in B. cinerea (De Bary) Whetzel, Fusarium oxysporum Schlecht., Mycosphaerella arachidicola Jenkins and Physalospora piricola Nose. 
According to Hleba et al. (2014), the methanolic fungi extracts of both fungi Ganoderma lucidum and Trametes versicolor showed the strongest antimicrobia activity against Saccharomyces cerevisiae. Equally, lower antimicrobial activity of fungi extracts against Gram-positive microorganisms was detected by them But they didn't find antimicrobial activity of fungi extracts against Gramnegative bacteria and Candida albicans. On the other hand, antibacterial activity has been observed against Gram positive bacteria from the basidocarp extract of G. lucidum (Kim et al., 1993) and G. orogonense Murr. (Brian, 1951) Sudirman and Muziyati (1997) observed that seven Indonesian Ganoderma species inhibit the growth of Bacillus subtilis. Coletto and Mondino (1991) noted that methanolic extract of the mycelial and culture extract of $G$. recinaceum Boud and G. lucidum inhibited Bacillus subtilis Cohn. G. recinaceum also inhibited Staphylococcus aureus Rosen. Ethanolic extract from G. lucidum mycelium demonstrated significant anti-inflammatory effects (Kendrick, 1985).

There are also some studies on inhibitory and metabolic activities of polypores and bracket fungi in India. Quereshi et al. (2010) studied the antimicrobia activity of various solvent (aqueous, ethanol, methanol and acetone) extracts $(40 \mu \mathrm{g} / \mathrm{ml})$ of Ganoderma lucidum against six species of bacteria, viz. Escherichia coli, Staphylococcus aureus, Klebsiella pneumoniae, Bacillus subtilis Salmonella typhi and Pseudomonas aeruginosa. Sheikh et al. (2015) have reported the potential antioxidative role of two mushrooms G. lucidum and Trametes hirsuta in free radical systems. Bains et al. (2015) evaluated the potential of methanolic and ethyl acetate extracts of Agaricus sp. Morchella sp. and Canthrellus sp. against four bacterial strains $K$. pneumonia, P. aeruginosa, S. aureus and E. coli. Similarly, Sivaprakasam et al. (2011) tested aqueous and methanolic extracts of T. hirsuta fruit body against five pathogenic fungi (Penicillium sp., Aspergillu. fumigatus, Aspergillus niger, Aspergillus flavus and Mucor indicus and five bacterial stains (E. coli, P. aeruginosa, Salmonella typhi, S. aureus and Streptococcus mutans).

Polypores and bracket fungi are the major source of biologically active natura products extracted from the species of the diverse fungal phylum Basidomycota, furnishing a rich variety of active secondary metabolites and polysaccharides (Zjawiony, 2004). In the search for active compounds from Ganoderma species, the majority of research has been performed on extracts from the fruiting body and there have been fewer studies on extracts from the liquid cultivated mycelium (Russell and Paterson, 2006). It appears that there are a number of biologically active compounds to be found in the mycelium and the benefits of liquid cultivation over solid cultivation include: the ability to manipulate the cultivation medium to optimise mycelia growth; a shorter cultivation time; and less contamination. In fact, the reason that some of the Ganoderma preparations are not yet available as medicines may be from difficulties relating to mass production (Smith et al., 2002).

Considering the previous research reports on this antimicrobial aspects of Ganoderma lucidum and other species of bracket fungi and the fact that there is little or very scarce work on the antimycotic and antibacteria activities of extracts of G. lucidum and Polyporous officinalis, the present work was undertaken with an aim to find out the antimicrobial potential of these two bracket fungi against phytopathogenic fungi and bacteria through in vitro approach.

\section{MATERIALS AND METHODS}

\section{Material collection}

The fresh fruiting bodies of bracket fungi were collected from forest area near Solan district (situated between 76.42 and 77.20 degree East longitude and 30.05 and 31.15 degree north latitude) of Himachal Pradesh, India and sample was identified and confirmed with the help of Fungal Herbarium/Museum at National Centre for Mushroom Research and Training at Solan, Himachal Pradesh and Department of Plant Pathology, University of Horticulture and Forestry, Nauni, Solan, Himachal Pradesh, India.

\section{Preparation of aqueous extracts}

Aqueous extracts were prepared by adding $0.01 \mathrm{~g}$ of dried powdered fruit bodies of Ganoderma lucidum and Polyporus officinalis in $10 \mathrm{ml}$ of distilled water. The aqueous extract containing cellular debris was filtered through a fine muslin cloth to get a fine aqueous extract and then centrifuged at $1000 \mathrm{rpm}$ and the supernatant was filtered through the vacuum filter unit to remove any pathogenic fungi or bacteria and then transferred to a sterilized glass container. It was considered as pure $1000 \mathrm{ppm}$ solution and leveled as stock solution and from which respective concentrations (500 ppm and $250 \mathrm{ppm}$ solutions) prepared by adding required amount of distilled water. These extracts were used for further investigation.

\section{Preparations of ethanolic extracts}

These were also prepared in the similar way as mentioned above but ethanol was used instead of distilled water.

\section{Test pathogenic fungi used}

Efficacy of fruiting bodies of two bract fungi as mentioned above on the four fungi i.e. Aspergillus terreus, Alternaria solani, Fusarium oxysporum and Cavularia lunata were investigated by using standard method (Nene and Thapliyal, 1993)

\section{Determination of antimycobiotic activity}

For each fungi i.e. Alternaria solani, Aspergillus terreus, Curvularia lunata, Fusarium oxysporum three Petri plates were used. The technique used was poisoned food technique (Parkash et al., 2005). All the glassware in use, are sterilized properly by autoclaving for $15 \mathrm{~min}$ at $121{ }^{\circ} \mathrm{C}$. Medium was poured in the Petri plates mixed with different concentrations (i.e. $1000 \mathrm{ppm}, 500 \mathrm{ppm}$, $250 \mathrm{ppm}$ and control) of sample extracts under sterile conditions. Mycelia disc were taken from pure cultures of test fungi previously grown on PDA and were placed in the centre of the plates aseptically. Suitable negative control was also kept where the mycelia disc were grown under same conditions on PDA medium without supplementation of any sample compound. For positive control, Actidion (Cycloheximide) at $1000 \mathrm{ppm}(0.01 \%)$ was used in the medium as standard antifungal drug for comparison of antifungal action. The plates were grown at 27 ${ }^{\circ} \mathrm{C}$. The efficacy in each case was determined by measuring the additional mycelial growth each time after a proximal three days. The radial growth of the colony was measured in four directions at right angle to each other and average was taken. The percentage inhibition of the fungal extract was calculated by using formula:

$$
\text { Percentage inhibition }(\%)=\frac{\text { Control }- \text { Treated }}{\text { Control }} \times 100
$$

where $\mathrm{C}$ is control and $\mathrm{T}$ is treatment. Data was also analyzed statistically for $\mathrm{SEm}$ and $\mathrm{CV}$. The experiment was carried out in triplicate replications

\section{Test bacterial strains used}

The bacterial strains used were Bacillus subtilis (APR-4) and Escherichia coli (EC-1). These bacterial strains were procured from Kurukshetra University, Kurukshetra and Himachal Pradesh University, Shimla and were maintained on nutrient agar for further experiment.

\section{Determination of antibacterial activity}

The antibacterial susceptibility test was carried out using agar well diffusion test (Perez et al., 1990). The bacteria were cultured overnight at $35{ }^{\circ} \mathrm{C}$ in nutrient agar (Zhang et al., 2004). The final cell concentrations of bacterial rods were in the range of $10^{6}-10^{7} \mathrm{CFU} \mathrm{ml} \mathrm{m}^{-1}$.

The activity was checked against two pathogens i.e. Escherchia coli (EC-1) and Bacillus subtilis (APR- 4) and quantified using MIC (Minimum Inhibitory Concentration). Four nutrient agar plates (two for ethanolic and aqueous culture of each bacterium) were prepared and the media was made to settle down for 10 minutes. Wells were punched in the plates with the help of borer of size $8 \mathrm{~mm}$ to have uniform wells but the medium was not removed. The bacterial culture of respective strains were spread on the nutrient agar medium with the help of cotton swab and left for 5 minutes. Later, the medium from the wells was removed and the aqueous and ethanolic extracts of different concentrations (i.e.1000ppm, 500ppm, 250ppm) were poured into the different wells in the respective Petri plates with the help of micropipette. No extract was added in to the negative control well. For positive control, Ciprofloxacin $(0.05 \%=500 \mathrm{ppm})$ was used in a single well as standard antibacterial drug for comparison of antibacterial action in a separate Petri plate. The plates were incubated at $37^{\circ} \mathrm{C}$ for overnight and inhibition zone were recorded. The effect of fungal extract was expressed in terms of average diameter of the zone of inhibition measured in millimeter. Each test was carried out in triplicate replications.

\section{RESULTS AND DISCUSSION}

\section{Effect of Ganoderma lucidum (ethanolic extract) on test fungi}

There was complete inhibition of mycelia growth at 250ppm, 500ppm, 1000ppm for Alternaria solani. Aspergillus terreus, Fusarium oxysporum were also completely inhibited at $1000 \mathrm{ppm}$ and 500ppm but minimum inhibition observed at $250 \mathrm{ppm}$; whereas Curvularia lunata was also completely inhibited at $1000 \mathrm{ppm}$ and 500ppm and $250 \mathrm{ppm}$ concentration. In control sets, however no fungal or mycelia inhibition was observed. 
Table 1 Effect of Ganoderma lucidum (ethanolic extract) on mycelial growth of different fungi

\begin{tabular}{|c|c|c|c|c|c|}
\hline S. no. & $\begin{array}{l}\text { Concentration } \\
(\mathrm{ppm})\end{array}$ & $\begin{array}{c}\text { Alternaria } \\
\text { solani } \\
\text { (\% Inhibition) }\end{array}$ & $\begin{array}{c}\text { Aspergillus } \\
\text { terreus } \\
\text { (\% Inhibition) }\end{array}$ & $\begin{array}{c}\text { Curvularia } \\
\text { lunata } \\
\text { (\% Inhibition) }\end{array}$ & $\begin{array}{c}\text { Fusarium } \\
\text { oxysporum } \\
\text { (\% Inhibition) }\end{array}$ \\
\hline 1. & Actidion (Cy) 1000 & $99.8 \pm 0.10$ & $100 \pm 0.0$ & $100 \pm 0.0$ & $100 \pm 0.0$ \\
\hline 2. & Control (without extract) & $0 \pm 0$ & $0 \pm 0$ & $0 \pm 0$ & $0 \pm 0$ \\
\hline 3. & 250 & $100 \pm 0$ & $82 \pm 0.626$ & $100 \pm 0$ & $93.6 \pm 0.379$ \\
\hline 4. & 500 & $100 \pm 0$ & $100 \pm 0$ & $100 \pm 0$ & $100 \pm 0$ \\
\hline 5. & 1000 & $100 \pm 0$ & $100 \pm 0$ & $100 \pm 0$ & $100 \pm 0$ \\
\hline
\end{tabular}

\section{Effect of Ganoderma lucidum (aqueous extract) on test fungi}

In case of Alternaria solani, minimum mycelial inhibition was observed at 250ppm, 500ppm and maximum at $1000 \mathrm{ppm}$ whereas Aspergillus terreus was not completely inhibited at any concentrations. A minor mycelial inhibition percent was observed in case of A. terreus but Curvularia lunata and Fusarium oxysporum were completely inhibited at $1000 \mathrm{ppm}, 500 \mathrm{ppm}$ and $250 \mathrm{ppm}$.

Table 2 Effect of Ganoderma lucidum (aqueous extract) on mycelial growth of different fungi

\begin{tabular}{|c|c|c|c|c|c|}
\hline S. no. & $\begin{array}{l}\text { Concentration } \\
(\mathrm{ppm})\end{array}$ & $\begin{array}{c}\text { Alternaria } \\
\text { solani } \\
\text { (\% Inhibition) }\end{array}$ & $\begin{array}{c}\text { Aspergillus } \\
\text { terreus } \\
\text { (\% Inhibition) }\end{array}$ & $\begin{array}{c}\text { Curvularia } \\
\text { lunata } \\
\text { (\% Inhibition) }\end{array}$ & $\begin{array}{c}\text { Fusarium } \\
\text { oxysporum } \\
\text { (\% Inhibition) }\end{array}$ \\
\hline 1. & Actidion (Cy) 1000 & $50.5 \pm 0.10$ & $70.6 \pm 0.05$ & $70.0 \pm 0.06$ & $60.5 \pm 0.06$ \\
\hline 2. & Control (without extract) & $0 \pm 0$ & $0 \pm 0$ & $0 \pm 0$ & $0 \pm 0$ \\
\hline 3. & 250 & $82 \pm 0.622$ & $05 \pm 1.030$ & $100 \pm 0$ & $100 \pm 0$ \\
\hline 4. & 500 & $82 \pm 0.622$ & $04 \pm 044$ & $100 \pm 0$ & $86 \pm 0.533$ \\
\hline 5. & 1000 & $87 \pm 0.536$ & $05 \pm 1.030$ & $100 \pm 0$ & $100 \pm 0$ \\
\hline
\end{tabular}

\section{Effect of Polyporus officinalis (ethanolic extract) on test fungi}

In Alternaria solani and Aspergillus terreus there was a complete mycelia inhibition observed at $1000 \mathrm{ppm}$ and minimum inhibition was observed at 500ppm, 250ppm concentrations respectively. Whereas Fusarium oxysporum had maximum mycelia inhibition at $1000 \mathrm{ppm}$ and $500 \mathrm{ppm}$ followed by $250 \mathrm{ppm}$ concentration but Curvularia lunata was completely inhibited at $1000 \mathrm{ppm}$, $500 \mathrm{ppm}$ and 250ppm concentrations.

Table 3 Effect of Polyporus officinalis (ethanolic extract) on mycelial growth of different fungi

\begin{tabular}{|c|c|c|c|c|c|}
\hline S. no. & $\begin{array}{l}\text { Concentration } \\
\quad(\mathrm{ppm})\end{array}$ & $\begin{array}{c}\text { Alternaria } \\
\text { solani } \\
\text { (\% Inhibition) }\end{array}$ & $\begin{array}{c}\text { Aspergillus } \\
\text { terreus } \\
\text { (\% Inhibition) }\end{array}$ & $\begin{array}{c}\text { Curvularia } \\
\text { lunata } \\
\text { (\% Inhibition) }\end{array}$ & $\begin{array}{c}\text { Fusarium } \\
\text { oxysporum } \\
\text { (\% Inhibition) }\end{array}$ \\
\hline 1. & Actidion (Cy) 1000 & $99.8 \pm 0.10$ & $100 \pm 0.0$ & $100 \pm 0.0$ & $100 \pm 0.0$ \\
\hline 2. & Control(without extract) & $0 \pm 0$ & $0 \pm 0$ & $0 \pm 0$ & $0 \pm 0$ \\
\hline 3. & 250 & $75 \pm 0.737$ & $95 \pm 0.48$ & $100 \pm 0$ & $90 \pm 0.32$ \\
\hline 4. & 500 & $89 \pm 1.025$ & $92 \pm 0.418$ & $100 \pm 0$ & $94 \pm 0.362$ \\
\hline 5. & 1000 & $100 \pm 0$ & $100 \pm 0$ & $100 \pm 0$ & $94 \pm 0.36$ \\
\hline
\end{tabular}

\section{Effect of Polyporus officinalis (aqueous extract) on test fungi}

In case of Fusarium oxysporum, Curvularia lunata and Alternaria solani, there were maximum mycelia inhibition observed at $1000 \mathrm{ppm}$ conc. while minimum mycelia inhibition was observed at $500 \mathrm{ppm}, 250 \mathrm{ppm}$ concentrations respectively.
Whereas a little mycelia inhibition was observed at 1000ppm conc. but there was very little mycelial inhibition observed at $250 \mathrm{ppm}, 500 \mathrm{ppm}$ concentrations respectively.

Table 4 Effect of Polyporus officinalis (aqueous extract) on mycelial growth of different fungi

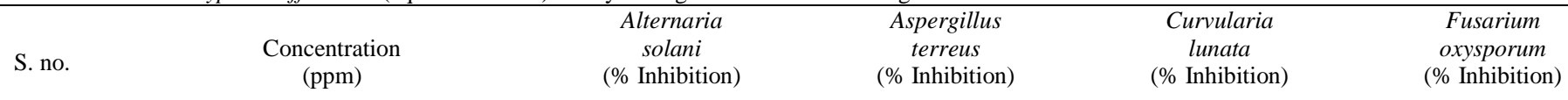

\begin{tabular}{|c|c|c|c|c|c|}
\hline 1. & Actidion (Cy) 1000 & $50.5 \pm 0.10$ & $70.6 \pm 0.05$ & $70.0 \pm 0.06$ & $60.5 \pm 0.06$ \\
\hline 2. & Control (without extract) & $0 \pm 0$ & $0 \pm 0$ & $0 \pm 0$ & $0 \pm 0$ \\
\hline 3. & $250 \mathrm{ppm}$ & $81 \pm 0.642$ & $1.0 \pm 0.0$ & $74 \pm 0.766$ & $84.7 \pm 0.47$ \\
\hline 4. & $500 \mathrm{ppm}$ & $82 \pm 0.622$ & $1.5 \pm 1.0$ & $78 \pm 0.702$ & $88 \pm 0.518$ \\
\hline 5. & $1000 \mathrm{ppm}$ & $87 \pm 0.536$ & $5.7 \pm 1.030$ & $82 \pm 0.622$ & $89.7 \pm 0.58$ \\
\hline
\end{tabular}

Effect of Ganoderma lucidum (ethanolic and aqueous extracts) on test bacteria

The minimum inhibitory concentration (MIC) was analyzed for aqueous and ethanolic extracts against two bacterial strains Bacillus subtilis (strain APR-4, Gram positive) and Escherichia coli (EC-1, Gram negative). The antibacterial action of ethanolic extract of $G$. lucidum was observed against $E$. coli having inhibitory zone $(0.09 \mathrm{~mm})$ at $1000 \mathrm{ppm}$ concentration and B. subtilis had inhibitory zone $(0.05 \mathrm{~mm})$ at $250 \mathrm{ppm}$ concentration respectively. The aqueous extract of $G$. lucidum had shown zero antibacterial activity/potential against $E$. coli and B. subtilis at any test concentrations.

Table 5 Activity of aqueous and ethanolic extracts of Ganoderma lucidum against different bacteria

\begin{tabular}{lccccc}
\hline S.no. & Bacterial Type & Bacterial strain & Type of extract & Minimum Inhibitory conc. (MIC) & Inhibition zone (mm) \\
\hline 1. & $\begin{array}{c}\text { Gram } \\
\text { negative }\end{array}$ & $\begin{array}{c}\text { Escherichia } \\
\text { coli }\end{array}$ & Ethanol Extract & 1000 & $0.09 \pm 0.06$ \\
\hline 2. & $\begin{array}{c}\text { Gram } \\
\text { positive }\end{array}$ & Bacillus subtilis & Ethanol Extract & 250 & $0.05 \pm 0.06$ \\
\hline 3. & $\begin{array}{c}\text { Gram } \\
\text { positive }\end{array}$ & E. coli & Aqueous Extract & - & No inhibitory zone \\
\hline 4. & $\begin{array}{c}\text { Gram } \\
\text { positive }\end{array}$ & B. subtilis & Aqueous Extract & - & No inhibitory zone \\
\hline
\end{tabular}


Effect of Polyporus officinalis (ethanolic and aqueous extracts) on test bacteria

The ethanolic extract of $P$. officinalis showed a maximum inhibitory zone $(10 \mathrm{~mm})$ at $1000 \mathrm{ppm}$ concentration for $E$. coli and a remarkable inhibitory zone
$(0.2 \mathrm{~mm})$ at $250 \mathrm{ppm}$ concentration for $B$. subtilis. While an inhibitory zone $(0.3$ $\mathrm{mm}$ ) was observed in $E$. coli at $250 \mathrm{ppm}$ concentration of aqueous extract; no inhibitory zone was observed for $B$. subtilis at any concentration of the aqueous extract of $P$. officinalis.

Table 6 Activity of aqueous and ethanolic extracts of Polyporus officinalis against different bacteria

\begin{tabular}{lcccc}
\hline S.no. & Bacterial strain & Type of extract & Minimum Inhibitory conc. (MIC\%) & 250 \\
\hline 1. & $\begin{array}{c}\text { Escherichia } \\
\text { coli }\end{array}$ & Aqueous Extract & Inhibition zone (mm) & .03 \pm 0.006 \\
\hline 2. & Bacillus subtilis & Aqueous Extract & 1000 & No zone of inhibition \\
\hline 3. & E. coli & Ethanol Extract & $10 \pm 0.0$ & 250 \\
\hline 4. & B. subtilis & Ethanol Extract & $.02 \pm 0.006$ \\
\hline
\end{tabular}

\section{Effect of Ciprofloxacin as a positive control on test bacteria}

Ciprofloxacin $(0.05 \%=500 \mathrm{ppm})$ in ethanol and distilled sterilized water were taken as positive controls and it showed maximum zone of inhibitions (18.4mm) against $E$. coli and $(20.2 \mathrm{~mm})$ against $B$. subtilis in ethanolic extract while maximum zone of inhibitions $(13.0 \mathrm{~mm})$ against $E$. coli and $(12.0 \mathrm{~mm})$ against $B$ subtilis in aqueous extract (see Table -7). But relatively antibacterial activity was low in sample extracts in comparison to standard positive control drug.

Table 7 Activity of aqueous and ethanolic extracts of Ciprofloxacin as a positive control against different bacteria

\begin{tabular}{|c|c|c|c|c|}
\hline S.no. & Bacterial strain & Type of extract & Minimum Inhibitory conc. (MIC in ppm) & Inhibition zone (mm) \\
\hline 1. & E. coli & $\begin{array}{c}\text { Ciprofloxacin } \\
(50 \mu \mathrm{g} / 100 \mu \mathrm{l}) \\
\text { (in Ethanol) }\end{array}$ & 500 & $18.4 \pm 0.041$ \\
\hline 2. & B. subtilis & $\begin{array}{c}\text { Ciprofloxacin } \\
(50 \mu \mathrm{g} / 100 \mu \mathrm{l}) \\
\text { (in Ethanol) }\end{array}$ & 500 & $20.2 \pm 0.06$ \\
\hline 3. & E. coli & $\begin{array}{c}\text { Ciprofloxacin } \\
(50 \mu \mathrm{g} / 100 \mu \mathrm{l}) \\
\text { (aqueous) }\end{array}$ & 500 & $13.0 \pm 0.04$ \\
\hline 4. & B. subtilis & $\begin{array}{c}\text { Ciprofloxacin } \\
(50 \mu \mathrm{g} / 100 \mu \mathrm{l}) \\
\text { (aqueous) }\end{array}$ & 500 & $12.0 \pm 0.02$ \\
\hline
\end{tabular}

Several previous researches have proved the antimicrobial activity of Ganoderma lucidum (basidiocarp and methanolic/ ethanolic extracts) against a wide range of zoo- and phyto-pathogenic fungi (Botrytis cinerea, Fusarium oxysporum Physalaspora piricola, etc.) and a few bacteria (Bacillus subtilis, etc.) (Sudhirman and Mujiyati, 1997; Coletto and Mondino, 1991; Kim and Kim, 1999). On the other hand, inhibitory action on mycelial growth in Botrytis cinerea, Fusarium oxysporum, Mycosphaerella arachidicola and Physalospora piricola was demonstrated by an antifungal polypeptide from fresh fruiting bodies of Polyporus alveolaris designated as 'alveolarin'. Similarly the positive antimicrobial effect was seen in case of $G$. lucidum and $P$. officinalis against the test microbes. So, the present study is exceptional on the aspect that it deals with the antimycobiotic potential of $G$. lucidum against some different phytopathogenic fungi as stated above; along with prospecting the potential of an unreported bracket fungus i.e. Polyporus officinalis (as a source of anti-fungal and anti-bacterial compounds.

To conclude this, the first report on the screening of the antimicrobial activity against the four fungal pathogens, viz. - Aspergillus terreus, Curvularia lunata Alternaria solani and Fusarium oxysporum and antibacterial activity against the two bacteria, viz. - Bacillus subtilis and Escherichia coli can serve as prospective potential aspect for much needed novel antibiotics. Further work is needed toward the evaluation of their antimicrobial potential against a wider range of microorganisms, identification of the bioactive principles and elucidation of their mechanism of action.

Acknowledgements: Authors are thankful to Rain Forest Research Institute (ICFRE), Jorhat, Assam, India and Shoolini Institute of Life Sciences and Business Management, Solan, Himachal Pradesh, India for providing the al possible facilities to carry out the experiment. They also thank Dr. Dinesh Kumar Chatanta for providing the culture of Bacillus subtilis (APR-4) for this study.

\section{REFERENCES}

BAINS, A., TRIPATHI, A., SHARMA, A. 2015. Antibacterial and Antioxidant properties of Wild Mushrooms collected from Himachal Pradesh. International Journal of Biology, Pharmacy and Allied Sciences, 4(10), 6161-6170.

BAO, X.F., WANG, X.S., QUN, D., FANG, J.N., LI, X.Y. 2002. Structural features of immunologically active polysaccharides from Ganoderma lucidum. Phytochemistry, 59, 175-181. http://dx.doi.org/10.1016/s0031-9422(01)00450-2 BRIAN, P.W. 1951. Antibiotics produced by mushroom. The Botanical Review, 17, 357-430. http://dx.doi.org/10.1007/bf02879038

CHEN, X., HI, Z., YANG, X.X., HUANG, M., GAO, Y., TANG, W., CHAN SY. 2006. Monitoring of immune responses to a herbal immuno-modulator in patients with advanced colorectal cancer. International Immunopharmacology, 6 , 499-508. http://dx.doi.org/10.1016/j.intimp.2005.08.026
COLETTO, B.M.A., MONDINO, P. 1991. Antibiotic activity in Basidiomycetes V. Antibiotic activity of mycelia and cultural filtrates. Allionia (Turin), 30, 6164.

JOHNSTON, N. 2005. Medicinal mushroom cuts off prostrate cancer cells blood supply. Drug Discovery Today, 10, 23-24. http://doi:10.1016/S1359$\underline{6446(05) 03657-3}$

KENDRICK, B. 1985.The fifth Kingdom. Mycologue Publication: Waterloo, Ontario, Canada, 375 p. ISBN-10: 0969223706.

KIM, B.K, CHO, H.Y., KIM, J.S., KIM, H.W., CHOI, E.C. 1993. Studies on constituents of higher fungi of Korea(LXVIII).Antitumour components of the cultured mycelia of Ganoderma lucidum. The Korean Journal of Physiology and Pharmacology, 24, 203-212. http://dx.doi.org/10.1007/bf02861310

KIM, H.W., KIM, B.K. 1999. Biomedicinal triterpenoids of Ganoderma lucidum (Curt.:Fr.) P.Karst. (Aphyllophoromycetideae). International Journal of Medicinal Mushrooms, 121-138. http://dx.doi.org/10.1615/intjmedmushrooms.v1.i2.20

LAKSHMI, B., AJITH, T.A., NAYANA, J., JANARDHANAN, K.K. 2006. Antimutagenic activity of methanolic extract of Ganoderma lucidum and its effect on hepatic damage caused by benzo(a)pyrene. Journal of Ethnopharmacology, 107, 297-303. http://dx.doi.org/10.1016/j.jep.2006.03.027

LIN, J.Y., CHEN, M.L., CHIANG, B.L., LIN, B.F. 2006. Ganoderma tsugae supplementation alleviates bronchoalveolar inflammation in an airway sensitization and challenge mouse model. International Immunopharmacology, 6 , 241-251. http://doi:10.1016/j.intimp.2005.08.009

LUKÁŠ, H, VUKOVIĆ, N., PETROVÁ, J., KAČÁNIOVÁ, M. 2014 Antimicrobial Activity of Crude Methanolic Extracts from Ganoderma lucidum and Trametes versicolor. Animal Science and Biotechnologies, 47 (2), 89-93.

NENE, Y.L., THAPLIYAL, P.N. 1993. Evaluation of fungicides. In: fungicides in plant disease control ( $3^{\text {rd }}$ ed.). Oxford and IBH publishing Co. Pvt. Ltd.: New Delhi, 531 p. ISBN: 8120402227.

PARKASH, V., AGGARWAL, A., SHARMA, S., GUPTA, S., GUPTA, A 2005. Antifungal activity of Withania somnifera L Dunal on some Phytopathogenic Fungi. Bulletin of the National Institute of Ecology, 15, 215 218.

PEREZ, C., PAULI, M., BAZERQUE, P. 1990. An antibiotic assay by the agarwell diffusion method. Acta Biologiae et Medecine Experimentalis, 15, 113-115. PERO, R.W., AMIRI, A., SHENG, Y., WELTHER, M., RICH, M. 2005. Formulation and in vitro/in vivo evaluation of combining DNA repair and immune enhancing nutritional supplements. Phytomedicine, 12, 255-263. http://dx.doi.org/10.1016/i.phymed.2004.01.008

QUERESHI, S., PANDEY, A.K., SANDHU, S.S. 2010. Evaluation of antibacterial activity of different Ganoderma lucidum extracts. People's Journal of Scientific Research, 3(1), 2010 9-13. 
RUSSELL, R., PATERSON, M. 2006. Ganoderma - A therapeutic fungal biofactory.

Phytochemistry,

67,

1985-2001.

http://dx.doi.org/10.1016/j.phytochem.2006.07.004

SHEIKH, I.A., VYAS, D., LONE, R., SINGH, V. 2015. Ganoderma lucidum and Trametes hirsuta as potent antioxidants in free radical systems in vitro. World Journal of Pharmacy and Pharmaceutical Sciences, 4(5), 1695-1710.

SHIEH, Y.H., LIU, C.F., HUANG, Y.K., YANG, J.Y., WU, I.L., LIN, C.H., LI,

S.C. 2001. Evaluation of the hepatic and renal-protective effects of Ganoderma lucidum in Mice. The American Journal of Chinese Medicine, 29, 501-507. http://dx.doi.org/10.1142/s0192415x01000526

SIVAPRAKASAM, E., KAVITHA, D., BALAKUMAR, R., SRIDHAR, S., KUMAR, J. S. 2011. Antimicrobial activity of whole fruiting bodies of Trametes hirsuta (Wulf. Fr.) Pil. against some common pathogenic bacteria and fungus. International Journal of Pharmaceutical Sciences and Drug Research, 3(3), 219 221

SLIVA, D. 2006. Ganoderma lucidum in cancer research. Leukemia Research, 30, 767-768. http://dx.doi.org/10.1016/j.leukres.2005.12.015

SMITH, J.E., ROWAN, N.J., SULLIVAN, R. 2002. Medicinal mushrooms: a rapidly developing area of biotechnology for cancer therapy and other bioactivities. Biotechnology Letters, 24, 1839-1845.

STANLEY, G., HARVEY, K., SLIVOVA, V., JIANG, J., SLIVA, D. 2005 Ganoderma lucidum supresses angiogenesis through the inhibition of secretion of VEGF and TGF-B1 from prostrate cancer cells. Biochemical and Biophysical $\begin{array}{lll}\text { Research } & \text { Communications, } & 330,\end{array}$ http://dx.doi.org/10.1016/j.bbrc.2005.02.116

SUDHIRMAN, L.I., MUJIYATI, S. 1997. Preliminary detection of antimicrobial activity of fruiting bodies' extract of tropical Ganoderma sp.. In: Proceedings of the $1^{\text {st }}$ International Symposium on Ganoderma lucidum in Japan. Toyoigakusha Co. Ltd., Tokyo; p. 154-159.

WANG, H., NG, T.B. 2006. Ganodermin, an antifungal protein from fruiting bodies of the medicinal mushroom Ganoderma lucidum. Peptides, 27, 27-30. http://doi:10.1016/j.peptides.2005.06.009

WANG, X.M., YANG, M., GUAN, S.H., LIU, R.X., XIA, J.M. 2006. Quantitative determination of six major triterpenoids in Ganoderma lucidum and related species by high performance liquid chromatography. Journal of Pharmaceutical and Biomedical Analysis, 41, 838-844. http://dx.doi.org/10.1016/j.jpba.2006.01.053

YUEN, J.W., GOHEL, M.D. 2005. Anticancer effects of Ganoderma lucidum: a review of scientific evidence. Nutrition and Cancer, 53, 11-17. http://doi:10.1207/s15327914nc5301 2.

ZHANG, Y.J., NAGAO, T., TANAKA, T., YANG, C.R., OKABE, H., KOUNO, I. 2004. Antiproliferative activity of the main constituents from Phyllanthus emblica. Pharmaceutical Bulletin, 27, 251-255. http://dx.doi.org/10.1248/bpb.27.251

ZJAWIONY, J.K. 2004. Biologically Active Compounds from Aphyllophorales (Polypore) Fungi. Journal of Natural Products, 67(2), 300-310. http://dx.doi.org/10.1021/np030372w 